Revue d'histoire de l'Amérique française

REYUE D.HISTOIRE DE L'AMÉRIQUE FRANÇAISE

\title{
The first Indian "Reserves" in Canada
}

\section{George F. G. Stanley}

Volume 4, numéro 2, septembre 1950

URI : https://id.erudit.org/iderudit/801634ar

DOI : https://doi.org/10.7202/801634ar

Aller au sommaire du numéro

Éditeur(s)

Institut d'histoire de l'Amérique française

ISSN

0035-2357 (imprimé)

1492-1383 (numérique)

Découvrir la revue

Citer cet article

Stanley, G. F. G. (1950). The first Indian "Reserves" in Canada. Revue d'histoire de l'Amérique française, 4(2), 178-210. https://doi.org/10.7202/801634ar d'utilisation que vous pouvez consulter en ligne.

https://apropos.erudit.org/fr/usagers/politique-dutilisation/ 


\section{THE FIRST INDIAN “RESERVES” IN CANADA}

From the outset of recorded Canadian history, the evangelization and civilization of the native aboriginal races has been the great aim of the Church. Man, even in his barbaric state, is a rational being; his moral consciousness may, from the standpoint of the European, be limited by the social factors of his environment, but it is never completely absent. To the Christian missionary, therefore, it has been a duty imposed by God to bring the Indian to an understanding of His mercy, to bring him to some appreciation of the white man's way of life, and to raise him from his primitive state of barbarism in order that he may share with the white man the dominant civilization of the North American continent. That the obstacles to an early realization of this ideal were insuperable was no deterrent to the missionary: to him it was simply a matter of effort and devotion. The task was Godimposed; the results would be God-given. Such an attitude, viewed in retrospect, was scarcely realistic; but it was one which did credit both to the good-will and the sincerity of the early French evangelists in Canada.

$$
\text { I - SILIERY }
$$

The first Indians with whom the Jesuit missionaries came in contact were the wandering Algonkian tribes. Of these the poorest, according to the Recollet historian Sagard, were the Montagnais who lived along the north shore of the St-Lawrence river in the vicinity of the Saguenay; richer were the Algonquin, whose hunting grounds were to be found further up the St-Lawrence above Quebec. It was thus in the heart of the Algonkian country that Champlain founded his colony of Quebec from which Le Jeune, the Jesuit superior, sent forth his men to cultivate the mission fields of Canada in the early years of the 17th century.

The greatest difficulty in the way of evangelizing the Indians of the St-Lawrence valley was their semi-nomadic pattern of life. The 
Algonkian tribes were not gathered together in fortified towns like the nations of the Iroquois Confederacy or the Hurons; they lived and hunted in small family groups and wandered hither and yon through the northern woods and valleys. To provide a chaplain for each Indian band was impossible; and yet Le Jeune felt that something had to be done to help those Indians, some of whom displayed an early interest in the teaching of the Christian religion and gave promise of becoming converts. It was obvious that if the work of evangelization was to go forward, the Indians would have to be induced to abandon their nomadism and settle down in fixed habitations. Before they could be converted to Christianity, they must be converted to a sedentary way of life. Father Le Jeune wrote in 1633:

...si je puis tirer quelque conclusion des choses que je vois, il me semble qu'on ne doit pas esperer grande choses des Sauvages, tant qu'ils seront errants; vous les instruisés aujourd'huy, demain la faim vous enlevera vos auditeurs, les contraignant d'aller chercher leur vie dans les fleuves \& dans les bois. ${ }^{1}$

On another occasion he wrote "si une fois on les peut arrester, ils sont à nous". ${ }^{2}$

To induce the Indians to settle down required a certain amount of bribery. The Algonkian tribes were seldom burdened with the good things of this life. They lived a hand-to-mouth existence. Too often they hovered on the verge of actual starvation; hence they hunted in small bands; hence they abandoned their sick; hence they listened to their medicine men and looked to charms for good luck in the chase. Should these wandering natives be led to believe that a sedentary life would produce more food and produce it easily, they might be inclined to embrace such a way of life and settle down in carefully supervised villages under the watchful eyes of their Jesuit mentors.

Father Le Jeune had no illusions regarding the attractions of the Christian faith for the Indians. The inducements which he held out were material rather than spiritual; they appealed to the stomach

1. The Jesuit Relations and Allied Documents, 1610-1791, edit., R.G. Thwaites (73 vols., Cleveland, 1896-1901), VI: 146. Henceforth this work will be cited as RDJ.

2. Ibid. 
rather than to the spirit. Fields and houses were to be supplied to the Indians; instructors were to assist the natives in their unaccustomed labours. That is why he wrote to France in 1634 asking for

quelque nombre d'hommes bien entendus à défricher \& cultiver la terre, lesquels se joignant avec eux sçauroient la langue, travailleroient pour les Sauvages, à condition qu'ils s'arresteroient, \& mettroient eux mesmes la main à l'œuvre, demeurants dans quelques maisons qu'on leur feroit dresser pour leur usage, par ce moyen demeurants sedentaires, \& voyants ce miracle de charité en leur endroit, on les pourroit instruire \& gaigner plus facilement. ${ }^{3}$

Le Jeune was no mere religious enthusiast. He was sufficiently practical in his approach to the Indian problem not to share the unrealistic view which had been expressed by Champlain and by some of his brother missionaries that the example of the prosperous white men would be sufficient to convince the Indians that farming was more profitable than hunting; he knew that actual help in cultivation was essential if the new project was to have any real chance of success. "Je fus frappé de ces pensées au commencement que nous vinsmes icy" he wrote "mais la comunication que j'ay eue avec ces peuples, \& les difficultez qu'ont des hommes habituez dans l'oisiveté d'embrasser un fort travail, comme est la culture de la terre, me font croire maintenant que s'ils ne sont secourus, perdront cœur..." 4

To establish an Indian settlement of the proportions planned and to furnish farm instructors in the numbers required was beyond Le Jeune's means. He might be able to supply a few bowls of hominy to the starving Indians who visited the missions at Notre-Dame des Anges and Notre-Dame de la Conception, but beyond this he could do little, by himself, to realise his scheme of founding Indian villages. Fortunately, to his assistance, came Noel Brulart de Sillery, a Knight of Malta and a member of the Company of the Hundred Associates, who, having become a priest, had dedicated his fortune to good works. Through the Jesuit Relations, de Sillery learned of Father Le Jeune's projects, and wishing to contribute to so pious an undertaking, he
3. Ibid., 144-6.
4. Ibid., 150 . 
provided the Jesuit superior with a sum sufficient to construct a chapel and other buildings, and placed at his disposal twenty workmen to prepare the fields for the Indians. His purpose, in his own words, was to help the Jesuits "arrester et assembler en lieu commode les sauvages errans et vagabonds, qui est le plus puissant moyen de leur conversion". ${ }^{5}$ The document embodying his gift is dated 1639, but de Sillery had given his orders two years earlier. It was thus in 1637 that the first workmen arrived from France to begin the task of building the Indian village, the site of which had been selected by Le Jeune and named by him after the benefactor, St-Joseph de Sillery. "Nous mismes ses ouvriers dans un bel endroit nommé à présent la Residence de S. Joseph, une bonne lieue au dessus de Kebec sur le grand fleuve", ${ }^{\circ}$ wrote Le Jeune in 1638. Among the buildings constructed at this time were the chapel, the Jesuit Residence, houses for the Indians and a hospital. In $1639 \mathrm{M}$. de Sillery placed the mission on a more solid foundation by undertaking to provide the Fathers with 1,500 livres annually during his lifetime, and to give them 20,000 livres on his death.

Two Algonkian families, numbering in all about twenty persons, consented to settle at Sillery and till the soil. The Jesuits were overjoyed. Here, at last, was the beginning of a sedentary Indian colony to which other Indians might be induced to come and in which they might be sheltered from their former savage associations and kept under French and Christian influences. It was with great enthusiasm and not a little humility that Le Jeune wrote:

Le bruit de cette assistance qu'on vouloit donner aux Sauvages se respandit incontinent dans toutes les nations circonvoisines: cela les a tellement touchées, que si avions les forces de leur donner les mesmes secours, on les reduiroit toutes en fort peu de temps. Et remarqués s'il vous plaist une grande benediction en cette affaire, pas un n'espere estre loge ny secouru qui ne resolve d'estre homme de bien, \& de se faire Chrestien, si bien que c'est une mesme chose en un Sauvage de vouloir estre sedentaire... ${ }^{7}$

5. R.P. Camille de Rochemonteix, s.j., Les Jésuites et la Nouvelle-France au $X V I I^{e}$ siècle (3 vols., Paris, 1895), 1: 247.

6. RDJ., XIV: 204.

7. Ibid., 212-4. 
Sillery developed rapidly. During 1638 thirty two Indians were baptised at the new sedentary mission; and during 1639, fifty six. ${ }^{8}$ In 1645 the parish registers show a population of 167 Christian Indians; and this despite the temporary dispersion of the Indians during the small-pox epidemic of 1639-40 in which the two original heads of families were struck down by the dread disease. ${ }^{9}$

In its early years, according to Rochemonteix, Sillery formed a centre of Christian piety and zeal which recalled the fervour of the first centuries of the Church. The Jesuits introduced the principle of electing chiefs, and Le Jeune recorded with great satisfaction that the Christian Indians had triumphed over the pagans in the election: "un seul Payen approcha du nombre des voix qu'eurent les Chrestiens" 10 . Two of the newly elected chiefs were detailed "qui tiendroient la jeunesse dans leur devoir" 11 and a third was made "Captain of prayers" 12. Such was their fervour that the Christian Indians, with an unchristian display of intolerance, proposed to exclude all pagans from the colony.

News of the Indian colony at Sillery spread far and wide. Christian neophytes from Sillery were largely responsible for the new mission which was opened at Tadoussac. ${ }^{13}$ In 1640 thirteen canoes of Attikamegues came to Sillery; after viewing the work of the mission they told Father Buteux "qu'ils avoient un grand désir d'estre instruicts, $\&$ de cultiver la terre" but preferred not to remain at Sillery "à raison qu'ils estoient differens d'humeur \& de la langue" from the Algonquins who had settled there. ${ }^{14}$ Even as far afield as the Huron of Georgian Bay and the Micmac of Miscou island did the reputation of the Sillery mission spread.

The Indian colony at Sillery was marked, not only by its religious fervour, but also by a real attempt on the part of its aboriginal in-

8. H.A. Scott, Une Paroisse Historique de la Nouvelle-France (Québec, 1902), 94. See also R.P. Léon Pouliot, s.j., La Mission Saint-Joseph de Sillery (L'œuvre des tracts, Montréal, aout 1937, no 218), 6.

9. RDJ., XVI: 103.

10. Ibid., XVIII: 100 .

11. Ibid., 102.

12. Ibid.

13. Ibid., XVIII: 110; XXI: 80.

14. Ibid., XVIII: 112. 
habitants to till the soil. Father Vimont, the new Jesuit superior, spent some time at Sillery in order to assist the Indians in this work. Neighbouring settlers also gave their help and their advice. ${ }^{15}$ The Journal des Jésuites informs us that in 1646 the Indians had begun "puissamment à travailler la terre". ${ }^{16}$ In one of her letters Marie de l'Incarnation wrote:

...nos pauvres Sauvages: car n'étant contents de se faire baptiser, ils commencent à se rendre sédentaires et à défricher la terre pour s'établir... C'est une chose admirable de voir la ferveur et le zèle des Révérends Pères de la Compagnie de Jesus. Le R.P. Vimont, supérieur de la Mission, pour donner courage à ses pauvres sauvages, les mene lui-même au travail, et travaille à la terre avec eux. ${ }^{17}$

And yet despite the efforts and zeal so highly commended by Marie de l'Incarnation the Sillery mission did not fulfil its early promise. The Jesuits were always handicapped by lack of funds for the Indian missions and by the poverty of their charges. The death of M. de Sillery and the political troubles into which France was plunged following the death of Louis XIII dried up the golden stream which had been required to keep the colony alive. Moreover, the Indians, despite the first optimistic reports of the Jesuits, did not take readily to agriculture. Father Vimont might do his best to set a good example by working in the fields himself, but his activities with the spade and hoe contributed in no way towards lessening the antipathy with which the Indians regarded the physical labour required to clear and cultivate the land. To add to the problems of the Jesuits at Sillery the Indian crops were poor and the meagre returns seemed but small compensation to the Indians whose thoughts were never far from the lost joys and freedom of the chase. More and more the Algonquin neophytes, content to live in French-built houses for part of the year, began to slip away upon prolonged hunting and fishing trips. It was useless for the Jesuits to try to prevent them. Father Vimont wrote in 1643:

15. Ibid., 108.

16. Journal des Jésuites (Montréal, 1893), 43-4; cited by le chanoine L. Groulx, "Missionnaires de l'est en Nouvelle-France", (La Revue d'Histoire de l'Amérique Française, vol. III, no 1, juin 1949), 55.

17. Marie de L'Incarnation, ed. Claude Martin (4 vols., Paris, 1929-39), III: 169-70; Marie de l'Incarnation à une dame de qualité, 3 sept. 1640. See also Rochemonteix, 1: 249. 
je ne sçay si on pourra continuer les secours \& les moyens qu'on nous donne pour remedier à ce mal, \& faire un arrest qui puisse estre stable de soy-mesme, la benediction que Dieu a donne sur les commencemens nous fait esperer un bon progrez \& une heureuse fin. ${ }^{18}$

But during the winter of 1649 the only inhabitants of Sillery were two white men. ${ }^{19}$

In order to save the mission Father Le Jeune in 1648 and Father Lalemant in 1650 both went to France to plead its cause. Money, above all, was needed; but money was not forthcoming. One important gift was, however, made to the Jesuits. To help the work of the mission the Company of New France, in 1651, conceded to the Indians, under the direction of the Jesuits, the seigneury of Sillery and the fishing rights in the St-Lawrence opposite the lands included in the grant. The wording of this grant makes it quite clear that, unlike the subsequent Indian grants, the lands in this instance were the property of the Indians. The pertinent paragraph of the letters patent reads as follows:

La compagnie de la Nouvelle-France ayant donné par un acte du troisième jour de mars dernier aux sauvages quy se retirent ordinairement proche de Québeq au dit pais, une lieue de terre sur le grand fleuve Saint-Lorent, bornée d'une part du cap qui termine l'ance de Saint-Joseph ou de Sillery du costé de Québec et de l'autre de l'endroit ou limite et finit cette lieue montant sur le grand fleuve sur quatre lieues de profondeur dans les bois ou dans les terres tirant au nord avec tout droit de chasse et de pêche... le tout sans aucune dépendance avec tous les droits de la seigneurie, sous la conduite et la direction des PP. de la compagnie de Jesus qui les ont convertys à la foy de Jésus-Christ et sans qu'aucun Français puisse chasser ou pescher dans cette btendue, sinon la permission du capitaine chrestien de cette nouvelle Eglise... De l'advis de la Reine régente notre très honorée dame et mère et de notre conseil qui a veu ladite concession dudit mars dernier, cy attachez soubz notre contre scel. ${ }^{20}$

18. RDJ., XXIV: 100.

19. Journal des Jesuites, 131.

20. Rochemonteix, I, Pièces Justificatives du tome premier, 467-9; "Lettres Patentes qui confirment la Concession de Sillery aux Sauvages". 
The Indians were not to be permitted to "remettre, concéder, vendre, ny alliéner lesdites terres que nous les accordons, ny permettre la chasse et la pesche à aucuns particuliers que par la permission desdits PP. et des capitaines chréstiens". The seigneury of Sillery may, therefore, be regarded as the first Indian "reserve" in Canadian history.

The formal grant of a reserved area for the use of the Indians did little to help the Jesuits in the work of conversion and civilization. Indeed the Indians were beginning to suffer from too much European civilization in its worst aspects. Sickness and drunkenness took their toll of the Mission's strength. And when the hospital was removed to Quebec in 1647 and the chapel and mission house were destroyed by fire in 1657 it seemed as if a blight had fallen upon the work which Father Le Jeune had undertaken with such confidence only twenty years before. The mission was rebuilt, but evidence of the change in its character is afforded by the facts that from 1660 grants were made of Indian lands to Europeans and that year by year the number of Indian baptisms grew less, finally disappearing altogether in 1669 and $1671 .{ }^{21}$ The Sillery colony was thus almost in complete eclipse when its prospects were brightened by the arrival of a number of refugee Abenaki in 1671 .

\section{II - St-Francors and Bécancourt}

When they first encountered the French in the early years of the 17th century the Abenaki lived in what is now the State of Maine. One of the tribes of the Abenaki confederacy welcomed the Jesuit Biard in 1612; but it was not until the 1640s that a missionary was sent specially to the Abenaki country. Nevertheless the Abenaki, an Algonkian people, maintained contact with other Algonkian nations living to the north; and during the hey-day of the Sillery mission several Indians of this nation visited the mission and became Catholic converts. It was these converts who, returning to their homes in New England, persuaded their brethren to forward a request to the French in Canada for a missionary to be sent among them. ${ }^{2}{ }^{2}$

In 1646 Father Druillettes was sent as a missionary to the Abenaki. He set himself to learn the Abenaki tongue and enjoyed consider-

21. Groulx, op. cit., 57.

22. RDJ., XXIX: 66-70. 
able success in converting these Indians to the Christian religion. ${ }^{23}$ He persuaded them to cease their inter-tribal warfare, forsake their pagan manitous and forego the white man's liquors. Other priests followed the trail blazed by Father Druillettes until 1660 when the Iroquois wars compelled the French to abandon the Abenaki missions. ${ }^{24}$ It speaks volumes for the efforts of these first peregrinating priests that some of their converts should, in the absence of their missionary, continue to make their way, from time to time, to the Sillery mission in order to renew their faith and strengthen their alliance with the French.

Militant Christianity and practical politics were no strange bedfellows in New France. More than once the missionary played the role of ambassador to the Indians and the maintenance of close relations with the Abenaki became a matter of the first importance to the civil authorities of Canada. Thus, during the frontier wars in that land of disputed boundaries, Acadia and New England, the Abenaki played a large part. Led by the Baron de Saint-Castin, an adventurer who not only lived among but married among them, the Abenaki carried fire and death to the Yankee settlers on the frontier. Abenaki tribes did not go unscathed at the hands of their hated English enemies. As early as 1675 about thirty Abenaki Indians emerged from the forests south of the St-Lawrence begging food and shelter at the Jesuit mission of Sillery, ${ }^{25}$ the first of many refugee Indian nations, Algonkian, Iroquois and Sioux who were to find homes in Canada.

By this date Sillery had become almost completely depopulated and the new arrivals were received with open arms. Others followed; first in small groups and later in bands, until the migration of the Abenaki to Canada developed into considerable proportions. Writing in August 1682 Father Bigot stated that within the last month "il est arrivé icy plus de cent personnes". ${ }^{26}$ The Abenaki were housed in the habitations formerly occupied by the Algonquins: and like their predecessors at the mission, they were taught, not only the Gospel, but also the arts of agriculture.

23. Ibid., XXXI: 182-6.

24. Abbé J.-A. Maurault, Histoire des Abenakis depuis 1605 jusqu'd nos jours. (Sorel, 1866), 155.

25. Rochemonteix, III: 224.

26. RDJ., LXII: 108. 
Unfortunately the land around Sillery quickly became exhausted with constant cropping, and the Jesuits, realizing the impossibility of trying to establish a sedentary colony in a place where the natives could see but meagre return for their efforts, resolved to seek out a new location. Father Jacques Bigot selected a site on the Chaudière River, not far from Quebec. Here, at the village of St-François de Sales, was established the new Abenaki colony. Some of the Indians preferred to remain at Sillery but the majority transferred to St-François de Sales where they formed a Christian colony which Father Beschefer considered as the one most firm in the Catholic faith and most devoted to the interests of France in the whole of North America. ${ }^{2} 7$

The new Chaudière colony grew rapidly in size. By 1688 the Sillery colony was virtually denuded of its Indian inhabitants, all of whom had moved either to St-François de Sales or to the Bécancourt river. Arrivals from the region of the Kennebec constantly added to the strenght of the Abenaki mission until, in 1689, the population of St-François de Sales totalled over 600. This increase in strength was much to the satisfaction of the civil as well as the ecclesiastical authorities if we may judge from the following remarks which the Governor of New France, Denonville, wrote to the Marquis de Seignelay in January 1690:

En partant du Canada, j'ai laissé une très grande disposition à attirer au christianisme la plus grande partie des sauvages abénaquis qui habitent les bois dans le voisinage de Boston; pour cela il faut les attirer à la mission nouvellement établie près de Québec sous le nom de Saint-François de Sales. Je l'ai vue en peu de temps au nombre de six cents âmes venues du voisinage de Boston; je l'ai laissée en état de s'augmenter beaucoup si elle est protégée...28

Further adhesions to St-François came as a result of the frontier wars of the 18th century. Attacks by New Englanders upon the Jesuit mission stations at Pentagoet and Norridgewock compelled greater and greater numbers of Indians to flee to Canada for refuge and pro

27. Ibid., LXIII. See R.P. J. Bigot's, “Journal de ce qui s'est passé dans la mission Abnaquise depuis la feste de Noël 1683 jusqu'au 6 octobre 1684"; also his "lettre au R.P. LaChaise, 8 novembre 1685".

28. Public Archives of Canada; Correspondance Générale, vol. II, cited in Rochemonteix, III: 229 , no 1 . 
tection. Abbé Maurault in his Histoire des Abenakis writes of Indian migrations of considerable proportion in $1722-3$ and 1724. 29

The lands originally occupied at St-François were granted to the Jesuits by Governor de la Barre on 1 July 1683. The grant was a small one, including an area only six miles square. The pertinent portion of the grant read as follows:

Le pères de la Compagnie de Jesus nous ayant exposé que plusieurs sauvages de la nation des Abnakis qui sont dispersés le long des terres anglaises... leur avoient fait connoistre qu'ayant dessein de venir s'habituer proche de nous et d'embrasser le christianisme, ils se seroient venus retirer auprès de ceux de leur nation qui font profession de la religion chrestienne sous leur conduite dans leur résidence de Sillery s'il y avoit eu place suffisante pour les recevoir et y faire du bleds-d'Inde pour leur subsistance, au défaut de quoy ils supplioient les dits pères de leur procurer des terres où ils pûssent jouir des mesmes avantages. Ce qui les avoit obliges d'en chercher dans d'autres lieux voisins... En conséquence des ordres du Roy, nous... avons aux dits pères de la Compagnie de Jesus concédé et accordé, concédons et accordons l'espace de deux lieues de terre de front, sur pareille quantité de profondeur le long des deux bords de la dite rivière du Sault de la Chaudière... pour estre par les dits pères distribuées aux Abnakis qui viendront dans la mission qu'ils y establiront embrasseront le christianisme et pour en jouir comme de choses à eux appartenant...30

Not all the Abenaki refugees established themselves at St-François de Sales. There were some who preferred to live along the St-Francis river. In 1700 Governor Callières decided to unite these groups into one Abenaki mission. His desire was to erect a strong barrier against the Iroquois and to provide an easily accessible pool of Indian warriors for the defence of Quebec. Accordingly, Father Jacques Bigot, the priest in charge of the Abenaki, was instructed to make the necessary arrangements with Dame Marguerite Hertel, widow of Jean Crevier, and her son Joseph Crevier, seigneur of Saint-Francis, for the cession of a portion of the Seigneury for the benefit of the Indians. This cession was agreed to, and the act of cession was sworn before the

29. Maurault, op. cit., 401-5.

30. Cited in Maurault, 234-5. 
notary, Adhemar, 23 August 1700. This act stated that, at the request of the Chevalier de Callières and the Intendant Champigny, Marguerite Hertel and her son

ont par ces présentes concédé aux dìts sauvages... et le révérend Père Jacques Bigot, de la Compagnie de Jesus, leur missionaire à ce présent et acceptant pour eux, une demye lieue de terre de front à prendre au bout d'en haut de la dite seigneurie de Saint-François, des deux costes de la rivière sur toute la profondeur de la dite terre avec les Isles et Islets qui sont sur la dite rivière par le travers de la dite demye lieue. Pour en jouir par les dits sauvages pendant tout le temps que la mission que les Pères Jésuites y vont établir pour les dits sauvages y subsistera. Et la dite mission cessante, la dite demie lieue présentement concédée en l'état que les dites terres seront alors, retournera à la dite damoiselle Crevier ès dits noms et au dit sieur son fils ou à leurs héritiers, pour leur appartenir comme auparavant le présent titre. ${ }^{31}$

Father Bigot, accompanied by 1,000 Indians, took up residence at the new location; after 1701 the Jesuit Relations make no further mention of the St-François de Sales Mission. ${ }^{32}$

In the following year further lands were acquired for the Abenaki. In 1701 the seigneur of Pierreville granted the Abenaki a portion of his seigneury. This grant is dated 10 May 1701. As in the case of the earlier grant, the seigneur retained a reversionary interest in the land should it be abandoned by the Indians and should the mission located there cease to exist.

In 1705 the Abenaki asked their missionary to request the Governor for a still further enlargement of their lands, arguing that the existing "reserve" was inadequate to maintain their families owing to the large increase in the population. ${ }^{33}$ Governor Vaudreuil, anxious to do all he could to retain the support and friendship of the Indians, persuaded the owners of the seigneury of Saint-Francis to give up another strip of land along the right bank of the river. This cession

31. Cited in Maurault, 278-9.

32. Sr. Marie Céleste Leger, The Catholic Indian Missions in Maine, 1611-1820 (Catholic University of America, Washington, 1929), 58.

33. R.P. Th. M. Charland, Histoire de Saint-François du Lac (Ottawa, 1942), 75. 
was made upon terms similar to those previously made on behalf of the Abenaki. It was formally ratified in 1712. ${ }^{34}$

Not all the Abenaki Indians in Canada were to be found at SaintFrancis; a number of families belonging to this nation had, as early as 1680, settled along the banks of the Becancourt river. No formal grant of land was made to these Indians at this time and it was not until 1708 that Governor Vaudreuil arranged with Pierre Robineau, baron of Portneuf and seigneur of Bécancourt, for the surrender of a portion of his lands for the use of the Indians. These lands like those at Saint-Francis, were to be "lent" rather than ceded outright to the Indians or to the Jesuits. The Bécancourt grant is dated 30 April 1708. After reciting the reason for and the size of the grant the document continued by stating that the lands specified were to be enjoyed by the Abenakis "tant que la mission subsistera entre les mains du Révérend père Rasle ou autres de la même compagnie, sans que les dits Abnakis ni ceux qui ont soin d'eux soient obligés à aucune redevance, le dit Sieur de Bécancourt n'ayant fait que prêter ses terres qu'autant que la mission subsistera". ${ }^{35}$

The Abenaki settlement at Bécancourt did not, however, become a permanent mission for some years and to such a low state did it fall that in $\mathbf{1 7 1 5}$ it was seriously considered whether it might not be to the advantage of both Abenaki colonies that they be merged. This certainly was the view held by de Ramezay and expressed by him in a letter to the minister in $1715 .^{36}$ But despite de Ramezay's proposals the two missions were not united. Each continued to remain separate from the other; and with the coming of Father Le Sueur, the Bécancourt mission took on a new lease of life and, for several years, enjoyed the reputation of being one of the most fervent Indian mission colonies in North America. ${ }^{37}$

It was, however, one of the great misfortunes of the Abenaki that they were, of all the Indian nations in Canada, the most inclined towards intemperance. Despite the efforts of the Jesuits, the Abenaki

34. Ibid., 75-6.

35. Cited in Maurault, 285-8.

36. PAC., C 11A, 35: 66, Ramezay et Begon au ministre, 7 novembre 1715 . See also Rochemonteix, III: 398 , no 1 .

37. Leger, op. cit., 63. 
missions at Saint-Francis and Bécancourt, like that at Sillery, became preferred markets for the brandy traders. Drunken brawls undid much of the good that had been accomplished; the civilization of the bootlegger seemed to achieve more than that of the priest. But however weak they were in spirit the Abenaki remained strong in the flesh; they never wavered in their alliance with New France and fought with more tenacity for the defence of Canada than any other Indian nation during the closing years of the Ancien Régime. And suffered too! In 1759 Robert Rogers' rangers descended upon the mission of Saint-Francis, burned it to the ground and slaughtered over 200 of its inhabitants. ${ }^{3} 8$ Brandy and warfare took heavy toll of the Abenaki and by 1760 their numbers had dwindled to about 700 at Saint-Francis and 300 at Bécancourt. ${ }^{39}$

\section{III - LORETTE}

Attempts to establish sedentary colonies among the Algonkian tribes had not yielded results commensurate with the devotion and effort expended ${ }^{40}$. It was not, however, from the wandering Algonkian Indians but from the sedentary Huron that the Jesuits hoped for the most solid results. On the shores of Lake Huron, in the stretch of country between Lake Simcoe and Georgian Bay, were to be found the most northerly of the Iroquois speaking nations. Like their kindred of the Confederacy, these Indians already lived in villages. They were agricultural, maize-growing Indians. They cultivated the soil. They were not always moving about from place to place. It would not be necessary to attract them to fixed locations or to persuade them by precept and example to try to learn to till their lands. Here were a people who could be moulded to the Christian faith, a people who might serve to point the way for other Indian nations to follow. The Huron offered the most promising prospects as far as the conversion and civilization of the Indians was concerned and it was into the Huron mission that the Jesuits put their greatest effort. And yet it was here

38. Journals of Major Robert Rogers (London, 1765), 147.

39. Maurault, 565.

40. Sedentary missions had also been attempted for brief periods at ThreeRivers and Miscou in Acadie; but neither of these missions ever attained the size or significance of the mission of St-Joseph de Sillery. 
that they encountered their greatest obstacles and met their most spectacular martyrdoms.

This is not the place to endeavour to retell the story of the annihilation of the Huron so vividly recorded in the pages of the Jesuit Relations and so brilliantly told by Parkman and Rochemonteix. Certainly no story contains more of the essential elements of heroic drama. The period of action is so brief; the contrast between the actors, priest and savage, so great; the denouement so tragic. Few there are who can read the tale of Brébeuf and his brethren without a sense of admiration for the men of the Huron mission: no men ever faced greater hardships or privation; no men ever showed greater endurance; no men ever displayed greater self sacrifice.

It is sufficient here to record the bare facts of history: the warriors of the Confederacy overcame the Huron, took their principal towns by assault, subjected their prisoners, European and Indian, to indescribable tortures and completely crushed the fighting spirit of the Huron nation. Huronia was left a land of desolation. Many of the Huron Indians were killed or carried into captivity; some were adopted into the tribes of the Confederate nations; a few sought safety with other Indian nations to the south and west emerging later in the vicinity of Detroit under the name of Wyandot; a small number took refuge with their spiritual guardians on the islands of Lake Huron. The light which Brébeuf had lighted in Huronia had been extinguished in blood.

In 1650 some of those who had fled to St-Joseph island in Georgian Bay entreated the Jesuits to lead them to Quebec, and there to form a colony under French protection. ${ }^{41}$ This proposal was accepted and a forlorn hope, but three hundred in number, made its way to Canada. The emaciated Huron reached Montreal in safety, travelling by way of the Ottawa river, but they were reluctant to settle in a region so exposed to the incursions of their dreaded enemies. Continuing down the St-Lawrence they reached Quebec on 28 July 1650. For a brief period they were housed with the Jesuits, the Ursulines, the Hospital nuns and various French families; subsequently they spent the winter at Beauport. Other Huron remained at Three-Rivers. In the spring of 1651 the Jesuits acquired, from Eléonore de Grandmaison,

41. RDJ., XXXV: 192-4. 
widow of the Sieur Chavigny de Berchereau, a tract of land on the island of Orleans for the benefit of the Huron. Here, close by the guns of Quebec, the remnants of the Huron nation settled down under the care and spiritual guidance of Father Chaumonot. ${ }^{42} \mathrm{~A}$ number of huts were constructed in the Huron manner and the whole village surrounded by a palisade. Being an agricultural people the Huron at once began to cultivate their lands or "reserve" as it would be called today. In 1651 Father Chaumonot wrote:

Nous avons aidé ces bonnes gens à défricher des terres... ils ont recueilly cette année une assez bonne quantité de bled d'Inde, tous neantmoins n'en auront pas suffisamment pour leur provision. Nous les secourerons comme nous avons secouru les autres, des charitez que l'on nous envoyera de France. ${ }^{43}$

The Huron colony on the island of Orleans increased in numbers with the arrival of isolated bands of Indians until it reached a total of approximately 600 souls.

The Huron, like the wandering Jew, seemed fated to be ever on the move. They were not long in their new home before emissaries arrived from the Five Nations bearing Greek gifts and inducements to the Huron to abandon the French and throw in their lot with the Iroquois. A number yielded and joined forces with the Mohawk and the Onondaga ${ }^{4}$. Those who resisted the peaceful persuasions of the Iroquois were attacked, no less than seventy of them, including a number of young women, being taken prisoners or put to death. ${ }^{45}$ Some of the inhabitants of Quebec wished to go to the assistance of their Indian allies, but the Governor, M. de Lauzon, as Abbe Ferland wrote, showed "plus de prudence que d'énergie", 46 and refused to do so. Charlevoix excuses the Governor's conduct:

Les Hurons par une suite de la présomptueuse confiance, dont les Sauvages ne sont point capables de se corriger, s'étoient lais-

42. Journal des Jésuites, 149. See also Rochemonteix, II: 119, no 1; also J.B.A. Ferland, Cours d'Histoire du Canada (2 vols, Québec, 1882), 1:388, no 1.

43. RDJ., XXXVII: 180.

44. Rochemonteix, II: 123.

45. R.P. F.-X. de Charlevoix, s.j., Histoire et Description Generale de la Nouvelle France (3 vols. Paris, 1744), 1: 323-4.

46. Ferland, op. cit., 1: 430 . 
sés surprendre: pour les arracher aux Iroquois, il eût fallu armer cinq ou six-cent Hommes, \& quand le Gouverneur Général les eût eus sous sa main, le tems nécessaire pour les armer $\&$ les embarquer auroit donné à ces Barbares une avance plus que suffisante pour rendre inutiles tous les efforts de ceux, qui les auroient poursuivis. ${ }^{47}$

Those who remained were reduced to "une petite poignée", no more than 150. ${ }^{48}$ About forty of this group joined Dollard in his famous exploit at the Long Sault.

In 1668 the Huron remaining under French control removed to the cote Saint-Michel near Quebec where, under the guidance of Father Chaumonot, they founded the mission of Notre-Dame-de-Foye. Wrote Father Mercier in the Relation for 1668-9:

La mission des Hurons est maintenant reduite à un petit nombre de personnes, mais ce sont gens choisis qui ayment la Religion Chrestienne, \& qui peuvent servir d'exemple à tous les autres. Depuis qu'ils ont veu la paix affermie avec les Iroquois leur ennemis, ils... se sont retirez dans les bois à une lieuë \& demie de cette ville [Québec], pour y cultiver des champs qui leur puissent fournir de quoy vivre, \& ils y ont fait un Bourg nouveau, \& comme une nouvelle Colonie. ${ }^{49}$

Several years later the Huron moved again, this time to a more secure abiding-place at Ancienne Lorette. Both wood and good land were wanting at Notre-Dame-de-Foye, but the new site possessed both, as well as a good supply of water. It had also the additional advantage of being close to the walls of Quebec which would afford protection to the harrassed Indians in the event of further Iroquois raids. The new mission was a long cherished dream of Father Chaumonot who had visited the celebrated sanctuary at Loretto in Italy. ${ }^{50}$ The settlement was prepared in the form of a square with the huts on the perimiter and the chapel, which was constructed along the lines of the Santa

47. Charlevoix, op. cit., 1: 324.

48. RDJ., XLV: 244; LIV: 286.

49. Ibid., LII: 228.

50. Rochemonteix, II: 124, no 2. See also Dr. J.G. Shea's edition of Charlevoix's, History and General Description of New France (6 vols, London, 1902), III: 154, no 4. 
Casa at Loretto, in the centre. The mission took the name of NotreDame de Lorette and was opened on 4 November 1674.

Meanwhile the Huron welcomed a reinforcement to their numbers in the persons of several Mohawk converts who had been compelled to seek refuge in Canada from the persecution of their pagan brothers ${ }^{51}$ : this, in the eyes of the Jesuits, was a true display of Christian spirit when one recalled to mind the terrible persecutions which the Huron had suffered at the hands of the Iroquois.

In 1675 Ancienne Lorette contained some 300 persons including both Huron and Iroquois. ${ }^{52}$ Ten years later, however, this number had fallen to 146, war and disease having decimated the inhabitants. ${ }^{63}$ In 1697 a final move was made to a new location on the St-Charles River which became known as Jeune Lorette. The land around Ancienne Lorette had become impoverished and frewood was no longer easily available, and in accordance with Indian custom the Huron preferred to move their huts rather than to make frequent journeys to the receding forest. Both Ancienne and Jeune Lorette were, incidentally, located on the seigneury of Saint-Gabriel originally granted to Robert Giffart but later given by him to the Jesuits. Finally, in 1793, the lands were transferred to the Huron Indians themselves with the proviso they be neither sold nor alienated. ${ }^{54}$ This last move marked the end of the Huron wanderings, for at Jeune Lorette the Huron remained, plodding slowly but surely along the road to racia! assimilation and civiljzation.

51. Charlevoix, 1: 435 .

52. RDJ., LX: 26.

53. Rochemonteix, III: 376.

54. The Act of Ratification, which is to be found in the Archives Judiciaires de Québec, contains a ratification of the concession of:

(a) the lands occupied by the Huron in their village, without power to sell or alienate

(b) a reserve of 40 arpents carrés granted the Huron March 7, 1742

(c) the free gift to the priest in charge of the Huron of the lands occupied by the presbytery and the flour mill

(d) the church, presbytery and other buildings pertaining thereto

(e) the sacred vessels, ornaments, cloth etc.

For the above information and for reference to Abbe L. St. G. Lindsay's work, Notre-Dame de la Jeune Lorette en la Nouvelle France (Montréal, 1902) and Father Chaumonot's Autobiographie, ed. R.P. Felix Martin, s.j. (1895). I am indebted to R.P. Adrien Pouliot, s.j. 


\section{IV - SAUlt St-Louis}

Despite the almost constant state of warfare which existed between the Indians of the Iroquois Confederacy and the Algonkian and Huron allies of the French, the Jesuits did not shirk the task of carrying the Christian gospel to their enemies. Fathers Jogues and Bressani, while prisoners of the Iroquois, had attempted to win converts among them, and when, after the conclusion of peace in 1653 , the Onondaga invited the French to estak lish a mission in the Iroquois country, the invitation was accepted with alacrity.

In 1654 Father Le Moyne was sent upon an exploratory visit to the Onondaga and Governor Lauzon granted to the Jesuits a tract of land ten leagues square in the Onondaga country for the proposed mission. The Jesuits were to be free to choose their own location and were to be accorded full seigneurial rights. In the following year Fathers Dablon, Chaumonot and Le Moyne, began their brief and precarious mission among the Onondaga and Mohawk. The missionaries enjoyed more immediate success among the Iroquois than they had at first experienced among the Huron. This was due partly to the large numbers of christianised Huron who had been adopted into the Five Nations; partly it was due to the Iroquois admiration for the courage displayed by the Jesuit Fathers. ${ }^{55}$ Unfortunately, the peace from which the Jesuits hoped for so much, came to an end in 1658. Forewarned, the French were able to slip stealthily away from the mission at dead of night while the Indians slept soundly "après avoir bien chanté, \& bien danse'". 6

Following the chastisement of the Iroquois by Courcelle and de Tracy, the Confederacy sued for peace and once more asked the French to establish a mission in their country. By 1667 the Jesuit missionaries were again active among the Iroquois. In that year Fathers Frémin, Bruyas and Pierron, arrived in the Mohawk country. Former Huron and Algonkian Indians adopted by the Mohawk were able to reveal themselves as Christians and with their assistance a number of noteable conversions were made, including the Onondaga chief, Garakontie, and the Mohawk, Kryn. Both pagan Indians and heretical English

55. RDJ., XLIII: 300; XLIV: 24.

56. Ibid., XLIV: 310. 
were alarmed at the success of the French and their opposition was such that the French were finally compelled to abandon the Iroquois mission in 1687. Several attempts were made to re-open it after that date by Fathers Bruyas, Lamberville, Le Valiant, d'Hue and Mareuil; but after 1708 the efforts of the French were directed Jess towards gaining converts among the nations of the Confederacy than persuading those who had accepted baptism to settle in Canada.

The fact is that the Iroquois converts were not a popular group among their own people. They were looked upon with suspicion and subjected to abuse and persecution by their fellows. To face unpopularity required more moral stamina than most Indians possessed and the Jesuits, knowing that their converts required constant encouragement and assistance to break with the habits and traditions of centuries and remembering the good example set by the sedentary colonies of Sillery and Notre-Dame de Foye in their earlier years, determined to draw the Iroquois converts or "praying Indians" from the cantons of the Confederacy and settle them in a sedentary colony in Canada. No great obstacle presented itself to the adoption of such a policy. The Iroquois were, after all, an agricultural people, accustomed after a primitive fashion to till the soil. A mission removed from the proximity of the Dutch and English and from the vices of their neighbours might achieve much in the way of evangelization and civilization, and, incidentally provide Canada with a strong body of Indian warriors in the event of attack. The Christian Iroquois were therefore encouraged, when they showed any inclination to escape the taunts of their own kindred, to go to Canada.

A suitable location for the new Indian colony was already available. In 1647 Governor de Lauzon had granted the Jesuits a tract of land on the south shore of the St-Lawrence extending from St-Helen's Island to the Lachine rapids or Sault St-Louis. The Jesuits had been unable to make any use of this grant at this date owing to its exposure to Iroquois attack, but after the conclusion of peace with the Iroquois and the establishment of the mission in the country of the Confederacy, Father Raffeix undertook to develop the lands which the Order had thus acquired on the south shore. In 1667 a chapel was built which was dedicated to St-François-Xavier, around which sprang up a French community which became known as La Prairie. Although it was not originally intended as an Indian mission, Christian Indians 
from time to time visited St-François-Xavier, among them Kryn, The Great Mohawk. Late in the summer of 1667 a small party of Oneida, including Pierre Tonsahoten, an old Huron convert whom Father Bruyas had found among the Iroquois, visited Montreal. Although only Tonsahoten was a Christian the Relation for 1667 stated that when

ces pauvres barbares qui ne sçavoient ce qui cestoit que de prestres d'eglise et de ceremonie estant entrés dans l'eglise du Montreal furent tellement ravis... qu'ls ne penserent plus aux iroquois d'ou ils venoient. ${ }^{57}$

The Oneida subsequently visited the Christian Huron at Quebec and were so impressed with their piety and sobriety that they accepted Christian baptism at the hands of Bishop Laval, returning afterwards to settle near Father Raffeix's chapel at La Prairie. Other Indians visiting Canada were also attracted to La Prairie and within three years twenty families, largely Iroquois, had settled here. In 1671 Father Dablon wrote:

il y en a quantité d'autres qui se disposent à descendre icy bas pour y faire profession de la Foy, qu'ils n'ont embrassée que dans le cœur n'ayant pas le courage de se déclarer Chrestiens parmi leurs gens encore infideles, \& pour des difficultez presque insurmontables d'y faire leur salut. ${ }^{58}$

By 1674 it was reported that 180 Indians had taken up permanent residence at the mission and were leading "une vie exemplaire." ${ }_{59}$

For some years the mission was relatively free from drunkenness and was regarded as a model of virtue among the several Indian villages. It produced the Indian saint, Katherine Tegakwita, who died in "an odour of sanctity" in 1680; it produced Indian apostles like Hot Powder, an Oneida alleged to have been one of the slayers of Brébeuf in 1649. But this initial display of fervour and piety was misleading. Every Indian mission had reported the same initial enthusiasm, then came a falling from grace as time proceeded. Such had

57. Ibid., LXIII: 150-2.

58. Ibid., LIV: 282.

59. Ibid., LVIII: 250. 
been the case at Sillery; such was the case at Saint Francis; such was to be the case at La Prairie or Kentaké, as the Indians called it. In 1681 the Jesuit Relations reported only a few isolated instances of drunkenness, the worst delinquents being expelled from the village. Within a few years there is a change in the tone of the Relations. In 1683 the remarks about drunkenness at Kentake were defensive in character drunkenness is being kept out of the village but the battle against the bootlegger has not been won. It was indeed a lost cause, for the proximity of Montreal and the lack of assistance from the civil authorities made it almost impossible to prevent the Indians from obtaining spirituous liquors. In 1671 Governor Frontenac, at the request of the ecclesiastical authorities, prohibited the sale of intoxicants to the Indians at La Prairie and closed a tavern which had been opened near the mission: but several years later, owing to his animosity towards the Jesuits, Frontenac permitted the tavern to re-open its doors, ostensibly to sell liquor only to the white settlers. ${ }^{60}$

The only solution to the liquor problem seemed to lie in the removal of the Indians from temptation since temptation could not be kept from the Indians. The Indian colony must be moved to a new location. There were other arguments in favour of such a course. The fact is that the French settlers at La Prairie were growing in numbers and had already taken up the best areas for cultivation. The little plots which the Indians tilled were inadequate to raise sufficient corn to feed their families. Some of the Indians were even beginning to mutter things about returning to their former homes in the Mohawk valley.

Accordingly the Jesuits applied to the civil authorities for permission to remove the Indians further up the St-Lawrence river. Acting upon his own authority the Intendant Du Chesneau consented to grant to the Jesuits a tract of land comprising two leagues frontage on the St-Lawrence river opposite the Lachine rapids. Here the Indians might have their own reserve, their own lands, their own church: here they could participate as active worshippers in their own chapel rather than remain as silent onlookers in the chapel at St-FrançoisXavier with its white congregation. The move to the new location was made in 1676. Seldom was there greater enthusiasm or more real devo-

60. Ibid., LXIII: 198-200. 
tion displayed by Christian neophytes than among the Iroquois as they took over their new reserve at Kahnawake at the Sault St-Louis.

The move from La Prairie to Kahnawaké met with a cool reception from Governor Frontenac. Such an effort to segregate the Indians was contrary to the whole principle behind his domestic Indian policy based as it was upon the close mingling of the white men and the red ${ }^{61}$. At La Prairie the Indians and the whites had lived together and shared the same mission; at Kahnawake the Indians were to be by themselves. Frontenac therefore not only refused to confirm Du Chesneau's promise but wrote to King Louis XIV that he had no intention of giving the Jesuits title to the lands at the Sault St-Louis until he had received definite instructions to do so from the king himself. ${ }^{6}$ The king returned a curt reply to his irascible governor and on 31 October 1680 Frontenac affixed his seal to the grant.

The royal grant, dated at Fontainebleau 29 May 1680, ran in part as follows:

...desirous of contributing to the conversion and instruction of the said Iroquois, and to act favourably towards the said Petitioners, We have given them... the said piece of land called the Sault, containing two leagues of frontage, commencing at a point opposite the St-Louis Rapids, ascending along the lake in similar depth, with two Islands and Islets and the beach lying opposite and adjoining the lands of the said Prairie de la Magdelaine, on the condition that the said tract... will revert to us all cleared, when the said Iroquois will leave it. ${ }^{63}$

The Indians at the Sault St-Louis, although they had formerly fought against the French and the Algonkian nations, joined forces with the French in the wars which followed the return of Frontenac to France. Despite this fact, the loyalty of the Sault Indians was never, like that of the Abenaki, completely above suspicion. The Canadian

61. See Groulx, op. cit.; also G. F. G. Stanley "The policy of 'Francisation' as applied to the Indians during the Ancien Régime." (La Revue d'Histoire de l'Amerique Française, vol. III, no 3, décembre 1949: 333-348).

62. Rapport de l'Archiviste de la Province de Québec pour 1926-1927 (King's Printer, Quebec, 1927), 110, Frontenac à Louis XIV, 6 novembre 1679. 13-4.

63. Indian Treaties and Surrenders, 1680-1890 (3 vols., Ottawa, 1891), I: 
Iroquois were not willing to raise the tomahawk against their own kindred in the Confederacy. Too many of those living at "the praying castle" on the St-Lawrence had blood relations still living in the Iroquois cantons south of Lake Ontario for the French to expect them to take the warpath against the nations of the Confederacy. There was, moreover, a constant intercourse and trade between the pagan and the Christian Iroquois which neither the English nor the French could prevent. The Jesuits were not opposed to this intercourse. To them it offered opportunities to use their neophytes to win more converts in the cantons: but to the governor of New France it was a breach in the French fur trade monopoly through which beaver pelts that should be on their way to Quebec slipped through to the English traders at Albany. This, at least, was the burden of the complaints of the elder Vaudreuil.

Only a few years elapsed before the Iroquois of the Sault were again on the move. Indian lands under steady cultivation soon became impoverished and Montreal was still too nearby for the Jesuits to be able to control effectively the surreptitious liquor trade. Accordingly, the Indians moved further westward along the river first to Kanhawakon in 1690 and then to a new Kahnawake in 1696. From the latter we get the present day corruption of Caughnawaga.

These frequent moves were in no way disturbing to the Indian mind. The average life of an Iroquois town in the cantons of the Confederacy was little more than twenty years; as the surrounding territory became exhausted, the Indians simply packed up and moved to a new location. Indian methods of cultivation were crude in the extreme and the continual cropping of maize took a great deal of nourishment from the soil. Accordingly, in 1704, Father Cholenec represented to the Marquis de Vaudreuil:

Ces sauvages ne pouvaient plus rester dans leur village, parce que les terres y sont usées et les bois trop éloignés et que c'est une necessité indispensable pour eux de se placer ailleurs. (Les Sauvages ne cultivent que du bled d'inde qui dégraisse fort la terre, leurs terres ne peuvent pas leur durer longtemps). ${ }^{64}$

On 15th November the Intendant Begon wrote to Paris pointing out the determination of the Indians "de transporter leur village à deux

64. PAC., C 11A, 106: 380-4. See also RDJ., LXVII: 24-6. 
lieues au dessus sur le fleuve St-Laurent du même côté ou ils sont a présent" and emphasizing that the Confederate Indians, acting at the instigation of the English, were making every effort "soit par présents ou par menaces pour attirer chez eux tous les sauvages du Sault"; the only way to retain them in the French service would be "en leur accordant le changement qu'ils demandent et le fond nécessaire pour deserter deux arpents en quarri et $y$ faire une enceinte de pieux avec un nouveau fort et une église". 65

The terms of the original grant made to the Jesuits by Louis XIV in 1680 had been conditional upon the return of the land to the king should the Indians and the missionaries choose to leave it. Owing to the activities of the Jesuits and the labours of the Indians the greater part of the original land had been cleared of trees and was ready for occupation by European colonists: the Jesuits felt, not without some justification, that they were entitled to compensation for their improvements. Governor Vaudreuil sympathised with this point of view. He felt that it would be distinctly unfair to insist upon the reversionary clause, particularly as the Jesuits were about to incur new expenses in connection with the construction of the new village. In 1717, Father Lafiteau sent a petition to the Council of the Marine department in Paris asking that the restrictive clause be not applied and that the Jesuits be permitted to retain the original grant for their own use. ${ }^{6}{ }^{6}$ Lafiteau's petition was graciously received and the grant to the Jesuits was confirmed. It is interesting to note that the Council of the Marine department considered the possibility of issuing new letters patent to the Jesuits and Indians conjointly:

Qu'il falloit par de nouvelles lettres pattentes accorder aux Jésuites conjointement avec les Iroquois les terres du Sault St-Liouis qu'ils ont quitte, celles où ils s'établissent de nouveau actuellement et la lieue et demye d'augmentation concédée par M. de Frontenac. ${ }^{67}$

But in the end it was decided that the original deed would be sufficient

65. Ibid.

66. PAC., C 11A, 106: 402-5, Arrêt du Conseil de Marine concernant la mission des Jésuites, 8 février 1718.

67. Ibid.: 405-6. 
and that the document issued in 1680 would meet the requirements of the moment. 68

This was the fourth migration of the Iroquois of the Sault since the first settlement had been undertaken by Father Raffeix at La Prairie in 1667. Many of the Indians who made this move had been born in one or other of the three villages along the St-Lawrence, and had been brought up under French and Catholic influences. They had made some progress towards adjustment since they had been born into a Christian pattern of life and because of the ever increasing infiltration of European blood into their veins. During the various raids and expeditions which they carried out against the frontier settlements of New York a number of prisoners had been taken, both men and women, white and Indian. These prisoners were frequently adopted and sometimes married into the tribe; Silas Rice captured at Marlboro, Massachusetts, in 1703, Eunice Williams, one of the captives of Deerfield in 1704, Jacob Hill and John Stacey, two boys taken near Albany in 1755 , are outstanding instances of this. Peter Kalm, who visited Canada in 1749, was struck by the high degree of miscegenation and concluded that the Sault St-Louis or Caughnawaga Indians had a strong European strain in them. He was interested to find that they still clung to the Iroquois tongue but, with this exception, he could find but little difference between the Indian and the nearby French villages.

$$
\mathrm{V}-\mathrm{ST}-\mathrm{R} \text { EGIS }
$$

As the struggle between the French and the English in North America entered its final phase, both contestants made every possible effort to win the support of the Iroquois. English agents were active among the Caughnawaga Indians: French agents were sent among the Iroquois of the Confederacy. It was in accordance with this policy that the Marquis Duquesne invited the Confederate Indians to send representatives to an Indian conference to be held in Montreal in 1754. The Confederate Indians had never looked upon themselves as subjects of Great Britain; they might sympathise with the English, accept their presents and fight under their flag, but they still felt themselves free to make whatever arrangements they might choose with

68. E.J. Devine, s.j., Historic Caughnawaga (Montreal, 1922), 178. 
the French. Accordingly, Duquesne's council was attended by Indians from the Five (or, more correctly at this date), Six Nations. To them the French Governor put forward the proposal that a Mohawk colony be established in Canada, not at Caughnawaga, but in a new Indian village on the St-Lawrence above Montreal. A new settlement had, in fact, already been started two years earlier, by some Indians from Sault St-Louis. The soil around the old mission was once more growing less productive and about thirty families of the Sault announced their intention of seeking homes elsewhere on the banks of Lake St-Francis, sixty miles above Montreal. On 31 October 1754 Duquesne wrote to Paris that a number of Mohawk had agreed to join the Caughnawaga families who had proceeded to Lake St-Francis and urged the king to authorize the expenditure of such funds as might be necessary for the construction of a saw mill to provide the Indians with the lumber wherewith to build their houses ${ }^{69}$. The new colony, said the Governor, would not only provide New France with a valuable listening post in the direction of Oswego, but would serve as an outwork for the defence of Montreal. It was obviously not part of Duquesne's policy in encouraging the establishment of another sedentary Indian colony to deplete the strength of the old one at the Sault. It was simply designed to provide an additional centre of attraction for those Iroquois of the Confederacy who might be disposed to settle in Canada and thus add to the Indian strength in New France. At the very least it might be the means of preventing some of the Mohawk from being used by the English in the event of hostilities.

The new colony may be said to date from 1752 when thirty Caughnawaga families moved from the Sault under the guidance of Father Billard. ${ }^{70}$ After taking up temporary quarters at the head of Lake St-Francis, the mission was finally established at the mouth of the St-Regis river where a grant of land was obtained for the purpose of the colony from King Louis XV. The mission thus became known by the name of St-Regis, but the Indians called it Akwesasne. In 1759, the Jesuits built a mill at the new location. Although the mission was

69. Documents Relative to the Colonial History of the State of New York, edit., E.B. O'Callaghan (14 vols, Albany, 1856-83), X:266-7, Duquesne to de Machault, 31 octobre 1754 .

70. Abbé G. Forbes, "Saint-Régis", Bulletin des Recherches Historiques, 8 (1902): $12-3$. 
established just prior to the outbreak of the Seven Years War with the possibility of the war in mind, the St-Regis Indians took very little part in the hostilities: within a few years of founding of the mission the French cause in North America had suffered defeat and the political direction of Indian affairs passed from the hands of the French Governors to those of the British.

\section{VI - Lac des Dedx Montagnes}

Shortly after the Christian Iroquois had begun to settle at La Prairie, another Indian colony started of its own volition on the mountain visited by Jacques Cartier in 1535. Here in 1671 a group of Indians, consisting of eight warriors and their families, settled in the vicinity of Montreal ${ }^{71}$. To leave such a group for any length of time without spiritual help was unthinkable and five years later the Indian village on the mountain became a formal mission under the guidance of "the Gentlemen of St-Sulpice". In 1680, records of baptisms and deaths were started. The mountain mission soon found a benefactor in the person of François Vachon de Belmont who, like M. de Sillery, was prepared to spend a fortune - his own - upon the work of converting and civilizing the Indians. The mission therefore entered a period of expansion and prosperity. Houses were constructed for the priests and cabins for the Indians; a school was opened for the education of the native children. The colony grew in size but in so doing it differed from all the other Indian colonies established in New France: its members were not from one single Indian nation like those at the Sault and Saint-Francis but from several. Within the limits of the Mount Royal colony were gathered together a motley group of Huron, Algonquin, Pawnee, Iroquois, Foxes and even several Sioux from the far western territories. In all they numbered 210 souls $^{72}$.

The Sulpician mission of the mountain, like that of the Jesuits at La Prairie on the opposite side of the St-Lawrence river, was at the outset a course of edification to all who saw it. Unfortunately it fol-

71. Mgr O. Maurault, Nos Messieurs (Montréal, 1936), 207. See also same author, "Oka, les Vicissitudes d'une Mission Sauvage", Revue Trimestrielle Canadienne (juin 1930): 1-2.

72. Jbid., $207-8$. 
lowed the historical pattern of every sedentary Indian colony established in New France; the priests of the mission soon found themselves unable to compete with the bootlegger and the unscrupulous trader and it was not long before the Sulpicians began to consider whether or not it might be advisable to remove the mission and the Indians from the immediate environs of Montreal. In 1696, with the financial assistance of $M$. de Belmont, the greater part of the mountain mission was moved up the Laprairie River to a site near the Sault-aux-Récollets. A few Indians, preferring the stimulation - largely alcoholic afforded by the proximity of Montreal, remained at the village on the mountain until 1704.

Despite every precaution adopted by the missionaries, the evil of in'temperance became as prevalent at the Sault-aux-Récollets as it had been at Mount Royal. The mission, stationed as it was on the Ottawa river, was located on the main highway from Montreal to the western fur trading posts, and it was impossible to prevent the traders using this highway from turning a dishonest louis at the expense of the Indians of the mission. Some action had to be taken to keep the Indians from temptation and once more emigration was advanced as the remedy. The Sulpicians therefore proposed to remove their charges to a new site on Lake of the Two Mountains. Political factors were also involved in this move. The Governor of Montreal was anxious to keep the Indians within reasonable distance of Montreal for purposes of defence and when in 1714 the whole question was discussed by Governor Vaudreuil, de Ramezay, the Intendant Begon and M. de Belmont, superior of the Sulpician Seminary at Montreal. "Ils conviennent tous qu'il est nécessaire pour le bien de l'isle de Montréal et la mettre à couvert des insultes des autres sauvages en cas de guerre de placer ceux-ci à l'endroit demande" ${ }^{73}$. For the needs of the new sedentary mission M. de Belmont "représente qu'il faut pour placer cette mission 4 lieües de terrain avec les isles adjacentes et six lieües de profondeur et une lieüe de front avec pareille profondeur pour les missionnaires qui y seront employés" but he made it clear that, since the Indians "ne sont point capables de conserver les choses qui leur sont les plus nécessaires" the lands required should be granted to the

73. PAC., C 11A, 106: 422-4, Arrêt du Constil sur le changement proposé pour la mission du Sault-aux-Récollets, 31 mars 1716. 
Seminary of St-Sulpice rather than to the Indians themselves "à condition qu'il l'employera pour la Mission de ces sauvages" 74.

Governor Vaudreuil accepted the arguments advanced by M. de Belmont and expressed the view that "on pouroit accorder une demie lieue de terrain sur trois lieües de profondeur aux Missionnaires à condition que quand les sauvages abandonneront leur terrain celuy cy reviendra aussy au Roy" ${ }^{35}$. On 18 April 1718, the king agreed to the concession of the lands as specified, to the Sulpicians, on condition that the Indians be removed to the new location, that provisions be made for their instruction and that within seven years a fort and a church and other buildings ke erected 76 .

The move of the Indians to the new "reserve" took place in 1721. Between 880 and 900 Indians were involved ${ }^{77}$, and on 20 September $1722 \mathrm{M}$. Gay, their missionary, reported that the Indians of Lake of the Two Mountains had under cultivation a larger acreage than had those of the Sault ${ }^{78}$. But a change of environment, especially when that environment was still within easy reach of Montreal, did not kill the Indian taste for brandy; and for the remaining years of the Ancien Régime the Sulpicians were obliged not only to wage war against Indian superstition and pagan cults but to renew the old familiar battle against intemperance among their charges.

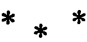

The establishment of the first Indian "reserves" during the Ancien Régime is significant in our history; it set the pattern of Canadian Indian policy at a very early date; it marked the beginning of the segregation policy which has been followed in Canada since the day that M. de Sillery provided Father Le Jeune with the means of founding the first Indian mission village near Quebec. In its broadest sense the Indian reserve is an area of land and its inhabitants, set aside from the general European community, within which exist a code of laws

74. Ibid.

75. Ibid.

76. Maurault, "Oka, les Vicissitudes d'une Mission Sauvage", 3.

77. Jean Dombreval, Archives et Souvenirs (Montréal, 1938), 111.

78. PAC., C 11A, 44: 126-7, Vaudreuil et Begon au ministre, 17 octobre 1722. 
and way of life differing from those of the dominant community. In this broad sense, the Catholic mission villages described above were technically Indian reserves. They were not in any way an innovation as far as native policy was concerned; the Spaniards had started the mission Colony system as early as 1516 when Cardinal Ximenes sent Jeronymites to the West Indies.

Segregation had not been the first policy attempted in Canada. Francisation had been the aim of church and state alike in the first years of the history of New France; but the church came soon to feel that the unrestrained mingling of the European and Indian peoples would effect only the physical idestruction of the latter and the moral degradation of the former. Never refusing to recognize the inevitability of assimilation in the long run, the Church desired that the process of acculturation should be gradual rather than sudden or immediate. The clergy argued that the first step must be the conversion of the Indian to the Christian religion; the improvement of his economic and social status was a secondary and subsequent objective. The Indian problem was a moral one as well as one of morale.

Because the emphasis was placed by the Church upon conversion, it should not be thought that the missionaries did nothing towards assisting the Indian to adapt himself to the white man's culture beyond giving him a crucifix. On the contrary, the missionaries did much to instruct the Indians, particularly the Algonkian Indians, in the rudiments of agriculture. Incompatibility of groups is the usual justification for segregation and without the segregated villages like Sillery, Saint-Francis, Sault St-Louis, St-Regis and Oka it is doubtful whether the Indians would have progressed as far as they did towards bridging the gap between stone age man and the civilization of 17 th and 18th century Europe. It is true that the missionaries did not use the sedentary colonies as schools for assimilation; that they allowed the Indians to use their own tongues and to follow many of their old habits and customs: it is true that they did not institute formal education for the Indians in these villages after the failure of Le Jeune's original boarding school experiment. ${ }^{79}$ But it should be realized that the Indians had scarcely reached the point of appreciating the advantages of formal instruction. It was probably better, as the Jesuits believed,

79. See note 61 . 
that the Indian should continue to hunt and to fish as well as to learn something of tilling the soil, for by these arts he would be able to provide for all his material wants. Within the reserve he might be taught something of Christianity and Christian morality and, to some extent, protected from the worst evils of the white man's civilization. Rightly or wrongly the Jesuits committed Canada to a policy of modified segregation.

One point of interest emerges with respect to the Indian reserves of the Ancien Régime. At no time was there any recognition on the part of the French crown of any aboriginal proprietary rights in the soil. The French settler occupied his lands in Canada without any thought of compensating the native. There were no formal surrenders from the Indians, no negotiations, and no treaties such as marked the Indian policy of the British period. The lands which were set aside for the Indians were granted not of right but of grace, not to the Indians themselves but to the religious orders who cared for them. The nearest approach to any grant to the Indians themselves was the Sillery grant of 1651 . Whatever rights the Indians acquired flowed not from a theoretical aboriginal title but from the clemency of the crown or the charity of individuals.

The absence of any formal recognition of the Indian title to be treated for and extinguished by mutual agreement did not, however, indicate a duller sense of social justice than that which prevailed during the British regime. The treaties of the 19th century were too often confusing to the minds of the Indians who neither understood the full significance of the negotiations into which they so freely entered nor the European concept of private ownership in land. Too many of the Indian treaties were used to cloak with robes of legality actions of dubious morality. The French may have denied the Indian any title to the lands over which he hunted, but they never looked down upon the Indian as an inferior type of human being. The aboriginal Canadian was not treated with cruelty or injustice in New France. He was never looked upon, at least by the religious orders, simply as a fighting machine, a useful ally in times of war, a necessary adjunct to the fur trade and a social nuisance otherwise. Throughout the history of the Ancien Régime the soul and the welfare of the Indian was an object of solicitude both to lay and ecclesiastical authorities alike; and it was that fact, more than any political considerations - al- 
though these can never be completely ignored - which prompted the church and the government to set aside for his benefit, lands which might be used for his spiritual and economic betterment.

George F.G. Stanley,

Professor of History,

Royal Military College of Canada 